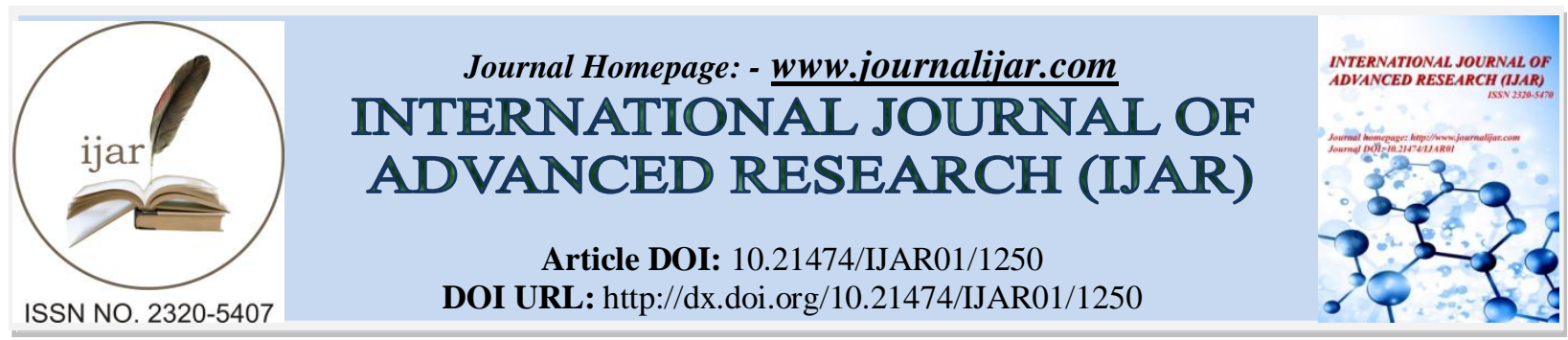

RESEARCH ARTICLE

\title{
FINANCIAL SECTOR DEVELOPMENT AND ECONOMIC GROWTH IN THE SELECTED EAST AFRICAN COMMUNITY COUNTRIES: EVIDENCE FROM PANEL UNIT ROOT AND COINTEGRATION TEST.
}

\author{
Asiimwe Julian \& Mbabazi Mbabazize, Okello John Paul.
}

Jomo Kenyatta University of Agriculture and Technology.

\section{Manuscript Info}

Manuscript History

Received: 12 June 2016

Final Accepted: 16 July 2016

Published: August 2016

Key words:-

Economic growth, Financial sector

development, East African Community

\section{Abstract}

This paper seeks to establish the relationship between financial sector development and economic growth in the selected East African Community Countries which include Uganda, Kenya and Rwanda using evidence from panel unit root and cointegration test basing on annual data from 2005-2015. The results from panel unit root indicate evidence of stationary variables after first difference while panel cointegration results indicate a unidirectional causality from financial sector development to economic growth in the long run which implies that financial sector development leads to economic growth in the selected East African Community Countries therefore policies aiming at developing the financial sector should be supported in order to achieve economic growth.

Copy Right, IJAR, 2016,. All rights reserved.

\section{Introduction:-}

Economic growth has been impressive in all three countries however much faster and sustainable growth is required in the region to absorb the rapidly rising labor force and materially improved living conditions. There is a need to raise GDP growth rates to above 7 percent a year on a sustainable basis in order to achieve the Millennium Development Goals. Other things being equal, attaining such high growth rates over long periods of time would imply investment-to-GDP ratios in excess of 25 percent, similar to those achieved in the periods of sustained high growth in Asian countries. It will also require substantial improvements in capital productivity.

The ratio of investment to GDP in the region is currently highest in Kenya (34.42 percent) and comparatively lower in Uganda (15.6 percent) and Rwanda (15.1 percent). The gross domestic savings in the region is also very low, standing on average at 12, 8.1 and 15.55 percent of GDP in Kenya, Uganda and Rwanda respectively and independently, putting into question the region's ability to maintain high growth rates on sustainable basis (E.A.C Secretariat report, 2012). Given the declining international assistance for financing investment, the region needs to achieve substantially higher rates of domestic savings in order to finance the required increases in investment thereby accelerating its growth and development. Attaining high rates of domestic savings will in turn require well developed and efficient financial sectors.

Previous studies suggest three types of causal direction between financial sector development and economic growth, namely; supply flowing phenomenon where financial sector development affects economic growth (Odhiambo and 
2009,Kigabo, Okello \& Mutuyimana, 2015, demand flowing phenomenon where financial sector development is said to simply follow economic growth(Waqabaca 2004,Abdelhafidh 2013) and bi-directional causality, where financial sector development leads to growth and growth as well leads to financial sector development(Kar and Pentecost 2000, Chuah and Thai 2004).

Various scholars using different methods either on developed or developing countries or both, have found conflicting results, therefore it is important to establish the exact relationship that exists between financial sector development and economic growth.

The main objective of this study is to establish the relationship between financial sector development and economic growth using the evidence from panel unit root and cointegration test in the selected East African Community( E.A.C) countries which are Uganda, Kenya and Rwanda basing on data from 2005-2015.Policies of the selected countries are based on the assumption that efficient utilization of resources through a highly organized, developed and liberal financial system enhances economic growth (McKinnon, 1973; Shaw, 1973).

At individual level, each of these selected countries have made policy efforts to develop efficient financial sector to achieve the Millennium Development goals, however Rousseau and Wachtel (1998) believe that theories of existing studies which were conducted on this topic towards resolving this issue are on developed economies such as U.S, U.K, Japan, Netherlands, Italy and Canada, among others. Lee and Wong (2005) reiterate that, the considered developing economies are majorly from Asia and Latin America, affording Africa in general and specifically East African Community very little coverage.

Even still, the few empirical research done on Africa has not clearly resolved the issue, as some support the view that financial development has a positive effect on economic growth in African countries (Allen and Ndikumana, 2000; Kigabo, 2015), while the studies carried out on Nigeria and Kenya for example have not clearly resolved the issue as most of them concluded that financial sector development did not promote economic growth while some of them (Agbetsiafa, 2003; Odhiambo, 2009) among others found evidence to support demand-flowing hypotheses. On the other hand (Akinlo and Egbetunde, 2010; Wolde-Rufael, 2009) performing the same study in Kenya, arrived at the same conclusion that there exists a bidirectional relationship between finance and growth. The researcher believes that the variation in the results produced by various researchers may have been due to different choice in econometric models and control variables.

Recent studies by Mugeme (2011), Okello et, al., (2015), Kigabo, et, al., (2015) used the model developed by Christopoulos \& Tsionas, (2003) for Panel data and not for time series data (Kay and Coe, 2016). Therefore this study was informed by the gap in the previous models used. Hence this study introduced Panel based Unit Root and cointegration test and Human capital and technology as control variables in line with Lucas, (1988). Levin, Lin and Chu (2002), Breitung (2000), Hadri (1999), and Im, Pesaran and Shin (2003) developed panel-based unit root tests that are similar to tests carried out on a single series. Interestingly, these investigators have shown that panel unit root tests are more powerful (less likely to commit a Type II error) than unit root tests applied to individual series because the information in the time series is enhanced by that contained in the cross-section data. In contrast to individual unit root tests which have complicated limiting distributions, panel unit root tests lead to statistics with a normal distribution in the limit and that is what most researchers have used in the past, especially in the EAC (Baltagi, 2001).

Thus this study contributed to the existing literature by examining the relationship between financial development and economic growth in East African Community. Financial sector development was proxied by the credit to private sector to GDP per capita $\left(c p s y_{t}\right)$, the ratio of bank deposit GDP per capita $\left(b d y_{t}\right)$, the ratio of $M_{3}$ GDP per capita $\left(m y_{t}\right)$ and economic growth proxied by GDP per capita $\left(y_{t}\right)$, while control variables introduced were human capital $\left(h c_{t}\right)$ and technology as $\left(\right.$ Tech $\left._{t}\right)$ all these were considered in order to clearly address the countrys' specific dimension to finance-growth debate. 


\section{Literature review:-}

The financial sector provides intermediation services that bring savers and investors together, theoretically channeling investment funds to the uses that yield the highest rate of return, thus increasing specialization and the division of labor (Todaro, 2003). Risk is pooled, transferred, and reduced by commercial banks while liquidity and information increase through the use of progressively more sophisticated financial products and technology.

Neoclassicals support the view that an increase in the efficient investment of savings in new and innovative projects is one of the main engines of economic growth. Neoclassical theory assumes that growth is a function of labor and capital which are supported by the level of technological advancement. i.e. $\mathrm{Y}=\mathrm{AF}(\mathrm{K}, \mathrm{L}) \mathrm{Where} \mathrm{Y}$ is Gross Domestic Product (GDP), $\mathrm{K}$ is the stock of capital, L is the amount of unskilled labor and A is exogenously determined level of technology. Note that change in this exogenous variable, technology, will cause a shift in the production function.

While according to the Harrod-Domar theory, for economies to grow they must save and invest a certain proportion of their income. Failure to develop is caused by the failure to save, and accumulate capital. For growth to happen, savings must be accumulated. i.e. Rate of growth $(\mathrm{Y})=$ Savings(s) / Capital output ratio (k)

Different empirical studies such as the ones by Fernandez and Galetovic (1994) and Arestis and Demetriades (1996) show that the direction of causality depends on the variables used and that different countries exhibit different results. However causality cannot be purely ruled out as empirical studies suggest three types of causal direction between financial sector development and economic growth which include;

Supply flowing phenomenon where financial sector development leads to economic growth: This is supported by some researchers who have explored causality with time series analysis such as Granger-type causality tests and vector autoregressive equations. Though some of these studies have mixed results over causality, nevertheless, majority of the works indicate that financial sector development leads to stronger growth. Xu (2000), using a Vector auto Regressive (VAR) analysis, rejects the hypothesis that financial sector development simply follows growth. Similarly, Chritopoulous and Tsionas (2004), using a panel data, show that causality runs from financial sector to economic growth. In support of the supply flowing phenomenon, King and Levine (1993a) use IMF data and various financial indicators to conclude that there is a positive relationship between financial sector indicators and growth, and that financial sector development is robustly correlated with subsequent rates of growth, capital accumulation, and economic efficiency. Odhiambo (2009c) set out to determine whether financial sector development which follows interest rate reforms causes economic growth in Kenya. He used a financial deepening model, Cointegration as well as the dynamic granger causality model and found that financial sector development caused by interest rate reforms influences economic growth both in the short and long run.

Demand flowing phenomenon where financial sector development is a result of economic growth is supported by researchers like Waqabaca (2004), while examining the relationship between financial sector development and economic growth in Fiji, finds a positive relationship between financial sector development and economic growth, but with the causation running from economic growth to financial sector development. Agbetsiafa (2003), while examining the causal relationship between financial sector development and economic growth in a sample of eight (8) emerging economies in sub-Saharan Africa (SSA), finds a unidirectional causality from growth to the finance dominate in Ivory Coast and Kenya. Abdelhafidh (2013) investigates the direction of causality between financial sector development and growth in North African countries over the period 1970-2008. Abdelhafidh (2013) distinguished between domestic saving and foreign inflows but also disaggregated the former into grants, FDI, portfolio investment and loans. Trivariate VAR models have been used to disentangle the direct and indirect impact of financial sector development on economic growth. The result indicates that economic growth Granger-causes domestic saving.

Bi-directional causality, where financial sector development leads to economic growth and at the same time economic growth leads to financial sector development. This is supported by some researchers like Kar and Pentecost (2000) who examined the causal relationship between financial sector development and economic growth in Turkey. The authors find that the direction of causality between financial sector development and economic growth is sensitive to the choice of measurement for financial sector development in Turkey. Calderon and Liu (2004), while using the Geweke decomposition test on pooled data for 109 countries, find some evidence of bidirectional Granger causality. Likewise, Chuah and Thai (2004), while investigating the causal relationship between 
financial sector development and economic growth in six Gulf cooperation Council (GCC) countries, using Error Correction Model (ECM) and Vector Auto Regressive (VAR) models, find that there is evidence of bidirectional causality in five of the six study countries. Calderon and Liu (2003) also find evidence of bi-directional causality between financial sector development and economic growth using the VAR and granger causality test based on the ECM model.

\section{Methodology:-}

The data used in the study was mainly secondary data. Panel data on GDP, Human Capital $\left(H c_{t}\right)$, and Technology $\left(\right.$ Tech $\left._{t}\right)$ was collected from National Institute of Statistics, and World Bank Indicators of the selected countries while data on financial sector development which include broad money, credit to private sector and bank deposits liability was collected from National Banks of Rwanda, Bank of Uganda and Commercial Bank of Kenya and IMF. All data is Panel data on annual basis from the 2005 up to 2015.

To measure economic performance, the quantity output expressed as index number (2006=100) was used (Christopoulos \& Tsionas, 2003). However to measure the financial sector development, the study employed three proxies. The essence of using three banking sector indicators was to allow for robustness test; so as to confirm whether consistent results could be obtained using different proxies. The first proxy is Broad money or $M_{3}$ to GDP per capita $\left(m y_{t}\right)$ which is a monetization measure, it is the broadest measure of money and thus of financial depth as it includes all financial institutions. It includes foreign reserves and other large deposits in addition to $\left(m_{2}\right)$ (Apergis et al., 2007). This proxy has been used for example by the World Bank (1989), Levine and King (1993a and 1993b) and Calderon and Liu (2003). The second is Credit to private sector as a ratio of to GDP per capita $\left(c p s y_{t}\right)$ used as a measure of financial depth. According to Beck et al. (2000) credit to private sector is superior to other measures of financial sector development because it excludes credit to the public sector and better reflects the extent of efficient resources allocation. It is based on the assumption that the private sector is more productive than the public sector when it comes to the utilization of funds. It is thus the most important measure of financial intermediary development, (Levine and Zervos (1998) and Yartey (2007). The third is Bank deposit liability to GDP per capita $\left(b d y_{t}\right)$ is as well important as it shows the liquidity of the banking sector (Levine and Zervos, 1998). The control variables; Human Capital $\left(H c_{t}\right)$ which should be considered per its effect on the economic performance (Odhiambo, 2009b). Technology $\left(\right.$ Tech $\left._{t}\right)$, which according to Barro and Sala-i-Martin (1995), Sala-iMartin (1997), McMahon (1998), Temple (1999), Bils and Klenow (2000), Self et al. (2004) find the same to be positively correlated with the growth rate of per capita Gross Domestic Product across countries.

To test for the normality properties of the variables, the study made use of the Jarque-Bera Test which compares the skewness and kurtosis coefficients of the variables. For a variable to be normally distributed, its skewness should be equal to zero, kurtosis should be equal to three and the JB statistics should be equal to zero.

Additionally, the study sought to determine the spread of the data estimating the mean and the first movement away from the mean for all the variables contained in the research models bellow. The researcher also conducted a graphical analysis of the variables to capture their movement over time.

To investigate the relationship between financial sector development and economic growth, the researcher used the following model developed by Christopoulos and Tsionas (2003) when they conducted a study of financial sector development and economic growth in 10 developing countries and in Rwandan case was improved by (Kigabo, Okello \&Mutuyimana, 2015; Okello, Kigabo \&Kitambala, 2015) .

$y=f(F, V)$

Where $y$ stands for GDP per capita, $F$ is the measure of financial development, while $V$ stands for control variables which are the human capital and technology, as variables which are determinants of economic output.

1. $Y_{t}=\beta_{0}+\beta_{1} m y_{t}+\beta_{2} c p s y+\beta_{3} b d y+\beta_{4} h c_{t}+\beta_{5}$ Tech $_{t}+\varepsilon_{t}$ 
Where $Y_{t}$ is the real output in year $t$; $c p s y_{t}$ is the credit to private as a ratio of GDP; $h c_{t}$ is human capital, Tech is the technology; $b d y_{t}$ in equation (3.2) is the ratio of banks deposits to GDP; $m y_{t}$ in equation (3.2) is the ratio of $M_{3}$ to GDP and $\varepsilon_{t}$ is an error term. The error term is guided by the following assumptions; No serial or autocorrelation, no Heteroscedasticity, and that there exist normality in the residuals.

In order to estimate elasticities in the long run relationships, the researcher introduced logarithms in the equation as follows:

$$
l Y_{t}=\beta_{0}+\beta_{1} l m y_{t}+\beta_{2} l c p s y+\beta_{3} l b d y+\beta_{4} l h c_{t}+\beta_{5} l T e c h_{t}+\varepsilon_{t}
$$

\section{Results:-}

Panel Regression Model Analysis:-

In order to distinguish between variables per country the researcher developed the panel regression model for the selected three countries using the fixed effect in table 4.1 bellow. This method allows for the heterogeneity that exists within each and every country (Granger, 1998).

Table 4.1:- Panel Regression Model.

\begin{tabular}{|c|c|c|c|c|}
\hline \multicolumn{5}{|c|}{ Dependent Variable: LY } \\
\hline \multicolumn{5}{|c|}{ Method: Panel Least Squares } \\
\hline \multicolumn{5}{|c|}{ Date: 04/21/16 Time: $14: 59$} \\
\hline \multicolumn{5}{|c|}{ Sample: 20052015} \\
\hline \multicolumn{5}{|l|}{ Periods included: 11} \\
\hline \multicolumn{5}{|c|}{ Cross-sections included: 3} \\
\hline \multicolumn{5}{|c|}{ Total panel (balanced) observations: 33} \\
\hline Variable & Coefficient & Std. Error & t-Statistic & Prob. \\
\hline LMY & -1.271088 & 0.497050 & -2.557266 & 0.0165 \\
\hline LHC & 0.314239 & 0.097467 & 3.224068 & 0.0033 \\
\hline LCPSY & 1.337901 & 0.365863 & 3.656830 & 0.0011 \\
\hline LBDY & 0.100679 & 0.476340 & 0.211360 & $\mathbf{0 . 8 3 4 2}$ \\
\hline LTECH & 0.137553 & 0.072043 & -1.909331 & 0.0469 \\
\hline $\mathrm{C}$ & 5.839970 & 0.207073 & 28.20249 & 0.0000 \\
\hline R-squared & 0.758653 & \multicolumn{2}{|c|}{ Mean dependent var } & 6.039924 \\
\hline Adjusted R-squared & 0.713959 & \multicolumn{2}{|c|}{ S.D. dependent var } & 0.343771 \\
\hline S.E. of regression & 0.183858 & \multicolumn{2}{|c|}{ Akaike info criterion } & -0.386338 \\
\hline Sum squared resid & 0.912703 & \multicolumn{2}{|l|}{ Schwarz criterion } & -0.114246 \\
\hline Log likelihood & 12.37458 & \multicolumn{2}{|c|}{ Hannan-Quinn criter. } & -0.294788 \\
\hline F-statistic & 16.97441 & \multicolumn{2}{|c|}{ Durbin-Watson stat } & 1.039348 \\
\hline Prob(F-statistic) & 0.000000 & & & \\
\hline
\end{tabular}

Panel regression model can be written as;

$$
l y=5.83-1.27 l m y+0.31 \text { lhc }+1.33 \text { lcps } y+0.1 \text { lbdy }+0.13 \text { ltech }+\mu
$$

This indicates that lcpsy, lbdy, ltech and lhc have positive impacts on the ly, with lmy having negative impact on the $l y$. This means that Credit to the private sector, bank deposits, Technological innovation and Human Capital are very important in regard to economic growth in the region this is in line with (Mugume, 2012). However ,direct Money Supply as expected has a negative influence on economic growth, this is means that the governments in the selected three countries should resort to other measures of increasing supply of money in the economy like encouraging commercial banks to increase their credit to private sector as a multiplier effect to growth (Verbeek, 2004). 


\section{Individual Significance:-}

From the table 4.1 above, it's important to check individual significance of the variables using the probability of test statistics for every variable as bellow;

\section{i. $\quad$ Significance of Money Supply $(\operatorname{lm} y)$ on GDP per capita $(l y)$}

$H_{0}: \alpha_{1}=0$ if the probability of $t$-statistics is $>5 \%$

$H_{1}: \alpha_{1} \neq 0$ if the probability of $t$-statistics is $<5 \%$

From the above table 4.1 , the probability of the $t$-statistics is equal to $1.6 \%$ which is less than $5 \%$, therefore the researcher rejected the null hypothesis and accepted the alternative hypothesis which means that the Independent Variable (lmy) significantly influences the Dependent Variable $(l y)$. However, the direction of the influence can't be identified at this point, because the alternative hypothesis only shows the evidence of a relationship between the Dependent Variable and the Independent Variable.

\section{ii. $\quad$ Significance of Human Capital $(l h c)$ on GDP per Capita $(l y)$}

$H_{0}: \alpha_{2}=0$ if the probability of $t$-statistics is $>5 \%$

$H_{1}: \alpha_{2} \neq 0$ if the probability of $t$-statistics is $<5 \%$

From the above table 4.1, the probability of the $t$-statistics is equal to $0.33 \%$ which is less than $5 \%$, therefore the researcher rejected the null hypothesis and accepted the alternative hypothesis which means that the Independent Variable $(l h c)$ significantly influences the Dependent Variable $(l y)$. However, the direction of the influence can't be identified at this point, because the alternative hypothesis only shows the evidence of a relationship between the Dependent Variable and the Independent Variable.

$$
\begin{aligned}
& \text { iii. Significance of Credit to Private Sector (lcpsy) on GDP per capita (ly) } \\
& H_{0}: \alpha_{3}=0 \text { if the probability of } t \text {-statistics is }>5 \% \\
& H_{1}: \alpha_{3} \neq 0 \text { if the probability of } t \text {-statistics is }<5 \%
\end{aligned}
$$

From the above table 4.1 , the probability of the $t$-statistics is equal to $0.011 \%$ which is less than $5 \%$, therefore the researcher rejected the null hypothesis and accepted the alternative hypothesis which means that the Independent Variable (lcpsy) significantly influences the Dependent Variable $(y)$. However, the direction of the influence can't be identified at this point, because the alternative hypothesis only shows the evidence of a relationship between the Dependent Variable and the Independent Variable.

$$
\begin{aligned}
& \text { iv. Significance of Bank deposits }(\text { lbdy }) \text { on GDP per capita }(l y) \\
& H_{0}: \alpha_{3}=0 \text { if the probability of } t \text {-statistics is }>5 \% \\
& H_{1}: \alpha_{3} \neq 0 \text { if the probability of } t \text {-statistics is }<5 \%
\end{aligned}
$$

From the above table 4.1 , the probability of the $t$-statistics is equal to $83 \%$ which is more than $5 \%$, therefore the researcher failed to reject the null hypothesis which means that the Independent Variable $(l b d y)$ does not significantly influence the Dependent Variable $(y)$. However, the direction of the influence can't be identified at this point, because the alternative hypothesis only shows the evidence of a relationship between the Dependent Variable and the Independent Variable.

v. Significance of Technological Innovation (ltech) on GDP per capita $($ ly $)$

$H_{0}: \alpha_{3}=0$ if the probability of $t-$ statistics is $>5 \%$

$H_{1}: \alpha_{3} \neq 0$ if the probability of $t$-statistics is $<5 \%$ 
From the above table 4.1, the probability of the $t$-statistics is equal to $4.6 \%$ which is less that than $5 \%$, therefore the researcher rejected the null hypothesis and failed to reject the alternative hypothesis which means that the Independent Variable (ltech) does significantly influence the Dependent Variable $(l y)$. However, the direction of the influence can't be identified at this point, because the alternative hypothesis only shows the evidence of a relationship between the Dependent Variable and the Independent Variable.

\section{Joint Significance:-}

To measure the joint significance between the Independent Variables (lmy,lcpsy, ltech, lhc,lbdy) and the dependent variable $(l y)$, the researcher considered the value of probability $F$-statistics (ANOVA) from table 4.1 above. This lead to the formation of the hypothesis bellow:

$$
\begin{aligned}
& H_{0}: \alpha_{1}=\alpha_{2}=\alpha_{3}=0 \text { if the probability of } F-\text { statistics is }>5 \% \\
& H_{1}: \alpha_{1} \neq \alpha_{2} \neq \alpha_{3} \neq 0 \text { if the probability of } F \text {-statistics is }<5 \%
\end{aligned}
$$

Since the probability of the $F$ - statistics from table 4.1 above is equal to $0.0000 \%$, which is less than $5 \%$, the researcher rejected the null hypothesis and failed to reject the alternative hypothesis meaning that all the Independent Variables lmy, lcpsy, lbdy, lhc, ltech have significant joint effect on the Dependent Variable $(l y)$.

\section{Checking for Normality of the Residuals in panel regression model4.1:-}

The standard assumption in linear regression is that the theoretical residuals are independent and normally distributed. The observed residuals are an estimate of the theoretical residuals, but are not independent (there are transformed on the residuals that remove some of the dependence, but still give only an approximation of the true residuals) Indiana, (2011). To test for normality in the population residuals, the study used Jarque-Bera test whose results are shown in figure 4.1 on the next page.

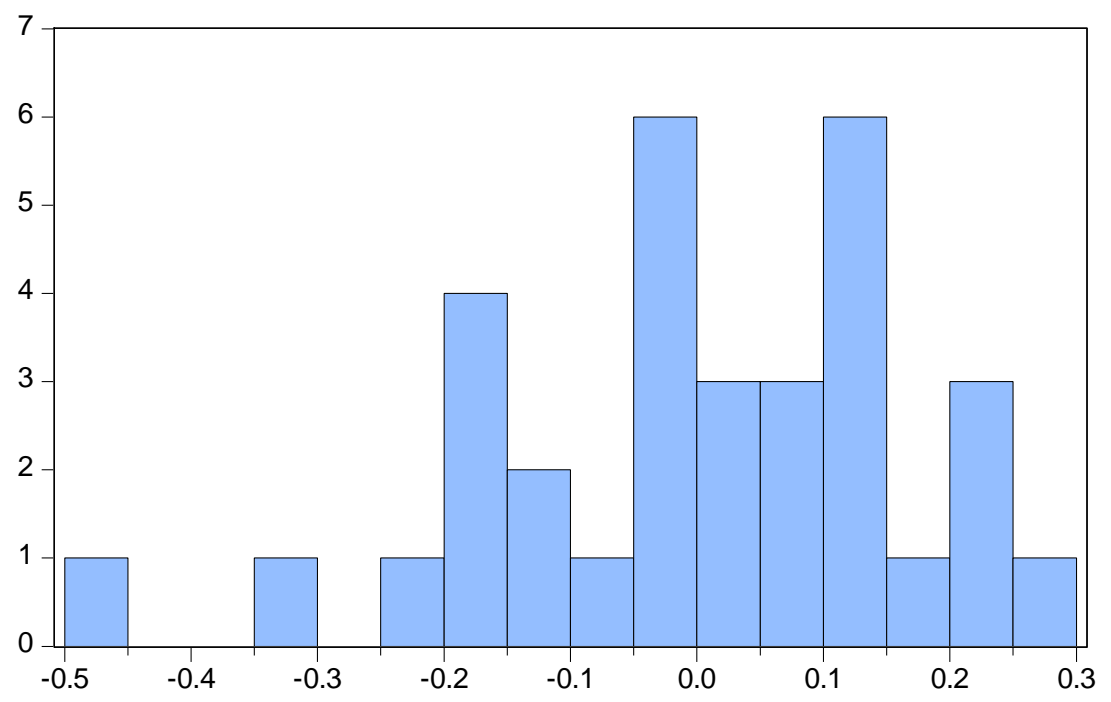

Series: Standardized Residuals Sample 20052015 Observations 33

$\begin{array}{lr}\text { Mean } & -7.65 \mathrm{e}-17 \\ \text { Median } & 0.023647 \\ \text { Maximum } & 0.266010 \\ \text { Minimum } & -0.472563 \\ \text { Std. Dev. } & 0.168885 \\ \text { Skewness } & -0.702169 \\ \text { Kurtosis } & 3.304472 \\ & \\ \text { Jarque-Bera } & 2.839194 \\ \text { Probability } & 0.241811\end{array}$

Figure:- Histogram-Normality Test for Normality of the Residuals in Panel regression model 4.1

To analyze the results of Jarque-Bera test in figure 4.1 above, the researcher set the following hypothesis;

$H_{0}$ :Residuals are normally distributed if probability of Jarque-Bera statistics $>5 \%$

$H_{1}$ :Residuals are not normally distributed if probability of Jarque-Bera statistics $<5 \%$

The probability of Jarque-Bera statistics from the figure 4.1 above is $24.1 \%$ which is greater than $5 \%$, hence the researcher failed to reject the null hypothesis implying that the residuals are normally distributed. 


\section{Panel Unit Root Test:-}

Pooled time series data, much like uni-variate time series data, tend to exhibit a time trend and are therefore nonstationary; i.e., the variables in question have means, variances, and covariances that are not time invariant. Engle and Granger (1987) argue that the direct application of OLS or GLS to non-stationary data produces regressions that are spurious in nature. These regressions tend to produce performance statistics that are inflated in nature, such as high R's and t-statistics, which often lead investigators to commit a high frequency of Type I errors (Granger and Newbold, 1974). Using the summary of Im, Pesaran and Shin t-test (2002) with null hypothesis stating that the panel data has unit root and alternative hypothesis stating that the panel does not have unit root, and Hadri (1999) with null hypothesis stating that the panel data is stationary or has no unit root and alternative hypothesis stating that panel data is not stationary, the result is displayed in table 4.2 bellow. Panel unit roots tests (both IPS and Hadri), reported in Table 4.2, support the hypothesis of a unit root in all variables across countries, as well as the hypothesis of zero order integration in first differences I(I). This finding is however in agreement with earlier research on the same by (Christopoulos \& Tsionas, 2004) and Okello, Kigabo \& Kitambala, 2015).

Table 4.2:- Panel Unit Root test.

\begin{tabular}{|l|c|c|c|c|c|}
\hline Variables & \multicolumn{2}{|c|}{ Im, Pesaran and Shin test } & \multicolumn{2}{|c|}{ Hadri Z-stat } & Remarks \\
\hline ly & $\begin{array}{c}\text { Probability - } \\
\text { Level }\end{array}$ & $\begin{array}{c}\text { Probability - } 1^{\text {st }} \\
\text { difference }\end{array}$ & $\begin{array}{c}\text { Probability - } \\
\text { Level }\end{array}$ & $\begin{array}{c}\text { Probability - } 1^{\text {st }} \\
\text { difference }\end{array}$ & \\
\hline lmy & $0.0050^{* *}$ & 0.4595 & 0.0002 & $0.0095^{* *}$ & $\mathrm{I}(0)$ \\
\hline lcpsy & 0.3458 & $0.0000^{* *}$ & 0.0090 & $0.3095^{* *}$ & $\mathrm{I}(1)$ \\
\hline lbdy & 0.6884 & $0.0000^{* *}$ & 0.0020 & $0.0977^{* *}$ & $\mathrm{I}(1)$ \\
\hline ltech & 0.3422 & $0.0140^{* *}$ & 0.0118 & $0.3334^{* *}$ & $\mathrm{I}(1)$ \\
\hline lhc & 0.0900 & $0.0001^{* *}$ & 0.0130 & $0.4521^{* *}$ & $\mathrm{I}(1)$ \\
\hline
\end{tabular}

\section{Panel Cointegration:-}

After finding that all the variables are stationary at I(1) the researcher ran the Panel Cointegration model as shown Tables 4.3 and 4.4 bellow. The researcher used two tests namely Pedroni (1999a) in table 4.3 and Kao (EngleGranger based) in table 4.4 and their results are conclusive: Pedroni (Engle-Granger based) test supports the presence of cointegrating vector. The Kao (Engle-Granger based) test also supports the hypothesis of a cointegrating relation. Therefore, all in all both panel-based tests concludes in support of a single cointegrating vector, and long run causality is unidirectional from financial sector development to growth which is in line with the findings of Christopoulos and Tsionas (2004) 
Table 4.3:- Pedroni's Panel Cointegration result.

\begin{tabular}{|c|c|c|c|c|}
\hline \multicolumn{5}{|c|}{ Pedroni Residual Cointegration Test } \\
\hline \multicolumn{5}{|c|}{ Series: LY LMY LBDY LCPSY LTECH LHC } \\
\hline \multicolumn{5}{|c|}{ Date: $04 / 22 / 16$ Time: $03: 48$} \\
\hline \multicolumn{5}{|l|}{ Sample: 20052015} \\
\hline \multicolumn{5}{|c|}{ Included observations: 33} \\
\hline \multicolumn{5}{|c|}{ Cross-sections included: 3} \\
\hline \multicolumn{5}{|c|}{ Null Hypothesis: No cointegration } \\
\hline \multicolumn{5}{|c|}{ Trend assumption: No deterministic trend } \\
\hline \multicolumn{5}{|c|}{ Automatic lag length selection based on SIC with a max lag of 0} \\
\hline \multicolumn{5}{|c|}{ Newey-West automatic bandwidth selection and Bartlett kernel } \\
\hline \multicolumn{5}{|c|}{ Alternative hypothesis: common AR coefs. (within-dimension) } \\
\hline & & & Weighted & \\
\hline & Statistic & Prob. & Statistic & Prob. \\
\hline Panel v-Statistic & -0.494422 & 0.0195 & -0.709576 & 0.0610 \\
\hline Panel rho-Statistic & 1.995642 & 0.0470 & 1.723048 & 0.9576 \\
\hline Panel PP-Statistic & -1.893288 & $\mathbf{0 . 0 2 9 2}$ & -0.748484 & 0.0271 \\
\hline Panel ADF-Statistic & -0.678524 & 0.2487 & -0.565125 & 0.0460 \\
\hline \multicolumn{5}{|c|}{ Alternative hypothesis: individual AR coefs. (between-dimension) } \\
\hline & & & & \\
\hline & Statistic & Prob. & & \\
\hline Group rho-Statistic & 2.585342 & 0.9951 & & \\
\hline Group PP-Statistic & -1.753153 & 0.0398 & & \\
\hline Group ADF-Statistic & -0.384770 & 0.3502 & & \\
\hline
\end{tabular}

Table 4.4:- Kao's Panel Cointegration result.

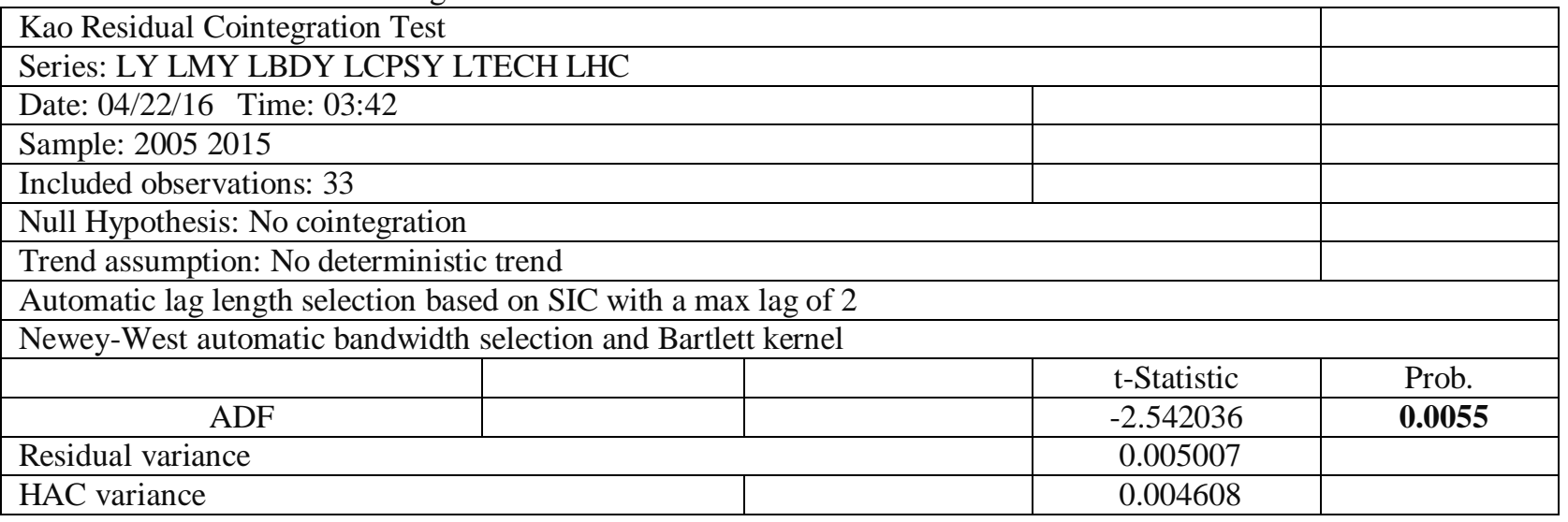

\section{Conclusion and policy recommendations:-}

This study used annual data from 2005 to 2015 to establish the relationship between financial sector development and economic growth using evidence from panel unit root and panel cointegration tests of the selected East African Community countries. To achieve this general objective, the research re-examined the common hypothesis in the finance-growth literature: the supply-leading, demand-following and bidirectional hypothesis. It applied the Panel cointegration tests by Pedroni (1999a) and Kao (1995b) to examine the long-run causal relationship between financial sector development and economic growth of the selected East African Community countries. The study utilized three financial sector indicators: a money supply ( $m y$ ), credit to private sector ( cpsy) and bank deposits ( $b d y$ ) while the control variables are Human capital ( $h c$ ) and Technology (tech).

The Panel based regression model concludes that the use of credit to the private sector as percentage of GDP per capita is relevant since it is more related to the ability of the financial system to channel funds from savers to borrowers (financial intermediation). The results indicated positive and significant impact of Credit to the Private 
Sector on economic growth of the selected EAC countries. In other words, the study established that coefficient of financial proxy variable (credit to private sector as a percentage of to GDP per capita is positive and statistically significant, supporting supply led hypothesis (Banking sector development leads to economic growth) this is in accordance with the predictions by McKinnon, (1973) and Shaw, (1973). This finding is consisted with the original study by King and Levine (1993) and later studies by Andrés, et., al. (1999) and Leahy, et., al. (2001), as they found significant links between bank credit to GDP ratios and subsequent economic growth rates in OECD countries.

The use of Bank Deposits to GDP per capita also indicated the consistency in supply lead hypothesis of the selected EAC countries as its coefficient is also positive and above all a statistically significant in the long run. As Levin, (1991) details that many projects or enterprises require a medium to long-term commitment of capital, whereas most savers prefer to have the option to draw on their savings, or move them into another investment opportunity, should the need arise i.e. they like their savings to be 'liquid'. Because banks and other financial intermediaries combine many households' savings, and because savers usually will not all want to withdraw their money at the same time, this allows financial intermediaries to simultaneously provide medium to long-term capital for investment, and liquidity for savers.

On the other hand, the Panel regression model indicated that $M_{3}$ herein denoted as money supply ( $m y$ ) is statistically significant but negative in the case of the selected EAC countries. This is in line with the findings of Mohamed, (2008) for the case of Sudan, but contrary to Kigabo, et., al, (2015) for the case of Rwanda, however the contradiction in findings is down to the inclusion of monetary policy variable in study done by Kigabo, et., al, (2015) which indicated that money supply without clear monetary policy is harmful to the Rwandan, Kenyan and Ugandan economy in the long run. Technology represented is shown to be statistically significant with a positive relationship. This means that the use of technology in Rwanda, Kenya and Uganda should be encouraged majorly through mobile banking.

On the same note, when the study used Panel cointegration tests by Pedroni (1999a) and Kao (1995b) test procedures, the overall results reveal evidence of unidirectional finance-led-growth of the selected East African Community countries in the long-run. This finding is in line with the findings of among others (Odhiambo, 2002; Zang and Kim (2007); Okello and Kigabo 2015).

The general conclusion is that there exists a supply flowing hypothesis from the financial sector development to economic growth of the selected EAC. In this paper we have combined cross-sectional and time series data to examine the relationship between financial development and growth in three developing countries.

The study has made use of panel unit root tests, and panel cointegration analysis to conclude that there is strong evidence in favor of the hypothesis that long run causality runs from financial sector development to economic growth, that the relationship is significant, and that there is no evidence of bidirectional causality but unidirectional causality. The empirical evidence also points to the direction that there is no short run causality between financial sector development and economic growth, so the effect is necessarily long run in nature.

The important policy implication is that policies aiming at improving financial sector of the selected EAC countries are important considering the variables used in this study. However money supply variable is herein significant but negative meaning that without clear monetary policy, money supply is harmful to the Rwandan, Kenyan and Ugandan economy in the long run. The use of technology especially through mobile banking should be encouraged. On the same points policy makers in these selected EAC countries should encourage savings through wide financial inclusion policies. This study achieved its general and specific objectives and the null hypothesis have been rejected meaning that all variables namely; $m y, c p s y, b d y, h c$, tech have a unidirectional cause to economic growth of the selected East African Countries. Such conclusions are in line with (Odhiambo, 2008). 


\section{References:-}

1. Abdelhafidh, S. 2013. Potential financing sources of investment and economic growth in North African countries: A causality analysis, Journal of Policy Modeling, Vol. 35(1), pp. 150- 169.

2. Abu-Bader, S., \& Abu-Qarn, A. M. 2008. Financial development and economic growth empirical evidence from MENA countries, Review of Development Economics, Vol. 12, pp.803-817.

3. Agbetsiafa, D. K. 2003. The Finance Growth Nexus: Evidence from sub-Saharan Africa Savings and Development, Vol.28 (3), pp271- 88.

4. Agu, C.C., \& Chukwu, J.O. 2008. Toda and Yamamoto causality tests between "bank based financial deepening and economic growth in Nigeria. European Journal of Social Science, Vol.7(2), pp.189-98.

5. Al-Awad, M., \& Harb, N. 2005. "Financial Development and Economic Growth in the Middle East", Applied Financial Economics, Vol. 15, pp. 1041-1051.

6. Allen, D., \& Ndikumana, L. 2000. Financial intermediation and economic growth in Southern Africa, Journal of African Economies, Vol.9(2),pp. 132-160.

7. Al-Malkawi, H. N.2007. Determinant of Corporate Dividend Policy in Jordan, Journal of Economic and Administrative, Vol. 23, pp. 44-71.

8. Apergis, N., Filippidis, I., \& Economidou, C. 2007. Financial deepening and economic growth linkages: a panel data analysis. Review of World Economics, Vol. 143(1): 179-198.

9. Arestis, P., \& Demetriades, P. 1997. Financial development and economic growth: assessing the evidence. Economic Journal Vol.107, pp. 783-799.

10. Aziz, J., \& Duenwald, C. 2002. Growth-Financial Intermediation Nexus in China. IMF Working Paper No. $02 / 194$.

11. Beck, T \& Levine, R. 2002. Industry Growth and Capital Allocation: Does having a market bank-based system matter? Journal of Financial Economics, Vol.64, pp.147-180.

12. Beck, T., Levine, R., \& Loayza, N. 2000. Finance and the Sources of Growth, Journal of Financial Economics, Vol. 58(1\&2), pp.261-300.

13. Ben Salem, J. B., \& Trabelsi, M. 2012. More on finance and growth in the MENA region: more growth, more finance, Middle Eastern Finance and Economics, Vol. 17, pp. 113-124.

14. Bencivenga, V. R., \& Smith B. D. 1991. Financial Intermediation and Endogenous Growth, Review of Economic Studies, 58(2), pp. 195-209.

15. Berthelemy, J. C, \& Varoudakis, A. 1996. Economic Growth, Convergence Clubs and the Role of Financial Development, Oxford Economic Papers, 48(2) pp.300-28.

16. Besci, Z., \& Wang, P. 1997. Financial Development and Growth, Economic Review 4th Quarter 46-62.

17. Blum, D., Federmair, K., Fink, G., \& Haiss, P. 2002. The financial-real sector nexus: Theory and empirical evidence. IEF working paper No. 43.

18. Bolbol, A. A., Fatheldin, A., \& Omran, M. M. 2005. Financial Development, Structure, and Economic Growth: The Case of Egypt, 1974-2002, Research in International Business and Finance, Vol. 19, pp. 171-194.

19. Boyreau-Debray, G., \& Wei, S. J. 2005. Pitfalls of a state-dominated financial system: The case of China, NBER Working Paper 11214.

20. Burgess, R., \& Pande, R. 2003. Do Rural Banks Matter? Evidence from the Indian Social Banking Experiment, typescript, LSE and Columbia University.

21. Calderon, C., \& Liu, L. 2003. The Direction of Causality Between Financial Development and Economic Growth, Journal of Development Economics, 72(1), pp.321-334.

22. Christopoulos, D.K., \& Tsionas, V. 2004. Financial Development and Economic Growth: Evidence from Panel Unit Root and Cointegration Tests, Journal of Development Economics, Vol. 73(1), pp. 55-74.

23. Chuah, H. L., \& Thai, V. 2004. Financial Development and Economic Growth: Evidence from Causality Tests for the GCC countries, IMF Working Paper, WP/04/XX.

24. Coleman, E. 1999.The Impact of Group Lending in Northeast Thailand, Journal of Development Economics, Vol.60 (1), pp.105-141.

25. De Gregorio, J. 1996."Borrowing Constraints, Human Capital Accumulation, and Growth", Journal of Monetary Economics, 37(1) pp. 49-71.

26. De Gregorio, J., \& Guidotti, V. 1995. Financial development and economic growth. WorldDevelopment, Vol.23(3): 433-48.

27. Demetriades, P. O., \& Hussein, K. A. 1996. Does Financial Development Cause Economic Growth? Time Series Evidence from 16 Countries, Journal of Development Economics, Vol.51 (2), pp. 387-411.

28. Easterly, W. R., \&Levine, R. 1994. Africa's growth tragedy. Paper presented at the African Economic Research Consortium (AERC) Workshop, Nairobi, Kenya, May. 
29. Enders, W., \& Granger, C. W. J. 1998. Unit root tests and asymmetric adjustment with an example using the term structure of interest rates. Journal of Business of Economic and Statistics No.16, pp.304- 312.

30. Fernandez, D., \& Galetovic, A. 1994.Schumpeter Might Be Right - But Why? Explaining theRelation between Finance, Development and Growth. Johns Hopkins University WorkingPaper in International Economics, No. 96- 01.

31. Fredric .S.Mishkin.1992. Anatomy of a financial crisis, Journal of Evolutionary Economics pp.115-130.

32. Galbis, V. 1997. Financial Intermediation and Economic Growth in Less- Developed Countries: A theoretical Approach. Journal of Development Studies January; 58-72

33. Geweke J., Meese, R., \& Dent, W. 1983. Comparing Alternative Tests of Causality in Temporal Systems: Analytical Results and Experimental Evidence, Journal of Econometrics, 21(2), pp.161-194.

34. Ghani, E. 1992. How financial markets affect long run growth: a cross-country study. World Bank Working Paper, vol. PPR 843. January.

35. Goldsmith, W. 1969.Financial Structure and Development, New Haven, CT. Yale University

36. Granger, C. J. 1969. Investigating Causal Relationships by Econometrics Models and Cross Spectral Methods, Econometrica, Vol. 37(3), 1969, pp. 425-435.

37. Granger, C. J. 1986. Developments in the Study of Cointegrated Economic Variables. Oxford Bulletin of Economics and Statistics, Vol. 48(3), pp. 213-28.

38. Greenwood, J., \& Smith, B. 1997. Financial Markets in Development and the Development of Financial Markets, Journal of Political Economy, Vol. 98(5) pp. 1076-107.

39. Guiso, L., Sapienza, P., \& Zingales, L. 2002. Does Local Financial Development Matter? NBER Working Paper W 89223, National Bureau of Economic Research, May.

40. Gurley, J.G., \& Shaw, E. S. 1955. Financial aspects of economic development. American Economic Review, Vol. 45(4), pp. 515-535

41. Jayaratne, J., \& Phillip E. S. 1996.The Finance-Growth Nexus: Evidence from Bank Branch Deregulation. Quarterly Journal of Economics, August, Vol.111 (3), pp, 639-760.

42. Johansen, S. 1995.Likelihood-Based Inference in Cointegrated Vector Autoregressive Models. Oxford, Clarendon Press.

43. Kar, M. \& Pentecost, E. J. 2000. Financial development and economic growth in Turkey: Further evidence on causality issue. Loughborough University, Department of economics, economic research papers No 00/27.

44. Kargbo, S.M., \& Adamu, P.A.2009. Financial development and economic growthin SierraLeone. Journal of Monetary and Economic Integration Vol. 9(2), pp.30-61.

45. Kigabo.R.Thomas, John Okello and Mutuyimana Jean Pierre. 2015. Financial Development,

46. Monetary policy and Economic Growth in Rwanda .BNR Economic Review, Vol. (7) pp. 79-99

47. King, R. G. \& Levine, R .1993c. Finance, Entrepreneurship and Growth: Theory and Evidence, Journal of Monetary Economics, Kuznets; 1955, Economic Growth and Income Inequality. Vol. 32(3), pp.513-42

48. King, R. G. \& Levine, R. 1993a. Financial Intermediation and Economic Development, in Financial Intermediation in the Construction of Europe, Eds. Colin Mayer and Xavier Vives.London: Centre for Economic Policy Research, pp.156-189

49. Kwan, A. C., Wu, Y., \& Zhang, J.1998. An Exogeneity Analysis of Financial Deepening and Economic Growth: Evidence from Hong Kong, South Korea and Taiwan. Journal of International Trade and Economic Development, Vol. 7(3), pp.339-54

50. Lee, C. C., \& Wong, S. Y. 2005. Inflationary Threshold Effects in the Relationship between Financial Development and Economic Growth: Evidence from Taiwan and Japan. Journal of Economic Development, Vol. 30(1), pp. 306-12.

51. Levin, A., \& Lin, C.F.1993. Unit root tests in panel data: asymptotic and finite sample properties. Mimeo (September). Vol.108 (1)

52. Levine, R.1997.Financial Development and Economic Growth: Views and Agenda, Journal of Economic Literature, Vol.32(2), 35, pp. 688-726.

53. Levine, R.1998. Financial Development and Economic Growth; Views and Agenda, Journal of Economic Literature, Vol. 35(2), pp.31-77.

54. Levine, R. 2000. Bank-Based or Market-Based Financial Systems: Which is Better? University of Minnesota, January.

55. Luintel, B. K., \& Khan, M.1999. A quantitative re-assessment of the finance-growth nexus: evidence from a multivariate VAR. Journal of Development Economics. Vol.60 (2), pp. 381-405.

56. Moslehi,A., Mohagharl, A., Badie1, K., Lucas, C. 2006.Introducing a toolbox for IC measurement in the Iran insurance industry, The Electronic Journal of Knowledge Management, Vol. 4 No.2, pp.169-80. 
57. Murinde\& Eng, F. H. 1994 .Financial Development and Economic Growth in Singapore:

58. Demand Following or Supply-Leading? Applied Financial Economics, Vol.4(6), pp. 391-404.Musoni, J. R. (2013) Threshold in the relationship between inflation and economic growth. Revised Final Report African Economic Research Consortium.

59. Ndebbio, J.E. 2004. Financial deepening, economic growth and development: Evidence from selected subSaharan African Countries. Research Paper 142 African Economic Research Consortium, Nairobi, Kenya, August.

60. Ndikumana, L. 2000. Financial determinants of domestic investment in Sub- Saharan Africa: Evidence from panel data, World Development, Vol. 28(2) pp. 381-400.

61. Neusser, K., \& Kugler, M. 1998. Manufacturing growth and financial development: evidence from OECD countries. The Review of Economics and Statistics, 638-646.

62. Nzotta, S. M., \& Okereke E. J. 2009. Financial deepening and economic development of Nigeria: An Empirical Investigation African Journal of Accounting, Economics, Finance and Banking Research Vol. 5.

63. Obstfeld, M. 1994. Risk-Taking, Global Diversification and Growth, American Economic Review, Vol. 84(5), pp.10-29.

64. Odedokun, M. 1996. Alternative Econometric Approaches for Analyzing the Role of the Financial Sector in Economic growth: Time Series Evidence from LDCs, Journal of Development Economics, 1996, Vol. 50 (1), pp. 119-46.

65. Odhiambo, N. M. 2008b.Financial Depth, Savings and Economic Growth in Kenya: A Dynamic Causal Linkage, Economic Modeling Vol. 25 pp. 704-713.

66. Odhiambo, N. M. 2004. Is Financial Development Still a Spur to Economic Growth? A Causal Evidence from South Africa, Savings and Development. Vol. 28(1):47-62.

67. Odhiambo, N. M. 2008. Financial development in Kenya: a dynamic test of the Finance-led growth Hypotheses. Economics issues, vol. 13(2), Pp 33.

68. Odhiambo, N. M. 2009b. Finance-Growth nexus and Inflation Dynamics in Kenya: an empirical

69. Investigation, Savings and Development, Vol. 33(1) pp. 7-25.

70. Okello John Paul, Kigabo.R.Thomas and Kitambala Marcellin .2015. Banking Development and Economic Growth in Rwanda. African Journal of Business and Industry Vol. (1) pp.50-77

71. Patrick, H. T. 1966. Financial Development and Economic Growth in Underdeveloped countries, Economic Development and Cultural Change, Vol. 14(1), pp. 174-189.

72. Rajan, R. G. \& Zingales, L. 1998. Financial Dependence and Growth American Economic Review 88, 559586.

73. Rousseau, L.P. \& Wachtel, P. 2000. Equity markets and growth: cross-country evidence on timing and outcomes, Journal of Banking and Finance Vol. 24, 1933-1957.

74. Rousseau, P. 1999. Finance, Investment, and Growth in Meiji-era Japan. Japan and the World Economy Vol.11, pp.185-198.

75. Schumpeter. 1911. Farsighted Visions on Economic Development, The American Journal of economics and sociology, Vol 61, No.2 (April 2002) pp.387-403

76. Spears, A. 1992. The role of financial intermediation in economic growth in Sub- Saharan Africa, Canadian Journal of Development Studies, Vol. 13(3), pp. 361-380.

77. Todaro, M. P., \& Stephen C. S. 2003.Economic Development. $8^{\text {th }}$ ed. Addison Wesley.

78. Waqabaca, C. 2004. Financial Development and Economic Growth in Fiji, Working Paper2004/03, Economics Department, Reserve Bank of Fiji. 